\title{
The 1-Hour Advising Session: Helping Students Choose Family Practice
}

\author{
Joseph E. Scherger, MD, MPH
}

"Your job is to make sure that every medical student who should become a family physician does so." This job description was given to me by the late George Snively in 1981. George was chair of the Department of Family Practice at the University of California, Davis, and I was starting my teaching career. At least in part, this job description is appropriate for all predoctoral faculty in family practice.

Despite the recent resurgence of medical student interest in family practice, and despite the market forces that make family practice attractive, many students are still discouraged from going into the specialty. Student interest in family practice usually holds strong during the first 2 years, as activities in family practice interest groups are convenient and reinforcing. Also, basic science faculty generally do not discourage students from a family practice career. During the 3 rd year, about one half of the students change their career interest, and attrition from family practice is common. We are all familiar with the discouragement medical students receive at the hands of some specialist faculty who still do not believe family practice is intellectually legitimate, and who seem oblivious to social needs and market realities .

In the spring of the 3 rd year, students are pressured to make a career choice so they can plan their 4th year and stay on track with residency selection. At this time many students who should go into family practice have the most doubts. Now is the time to undertake a "search and rescue operation" and to provide students with a 1-hour advising session.

If I can get students with family practice potential to come in for an appointment during this

Submitted 23 July 1997.

From the Department of Family Medicine, University of California, Irvine. Address reprint requests to Joseph $\mathrm{E}$. Scherger, MD, MPH, Department of Family Practice, UCI Medical Center, Building 200, Rt 81, 101 The City Drive South, Orange, CA 92868-3298. vulnerable period, the session usually goes something like this:

First I ask how they are doing and what their career interests are. A common answer is that they were considering family practice, but now they are on the fence in their choice between family practice and a couple of other specialties, for example, obstetrics-gynecology and pediatrics ("I like caring for the mothers and babies"). Sometimes a third specialty is being considered, such as psychiatry.

If students express a clear interest in a single specialty other than family practice, giving good reasons why they have "fallen in love" with this specialty above all others, I wish them well and end the interview by offering them any help I can. I try to make sure that they have at least a healthy respect for family practice.

If a student's interests are diverse and clearly directed toward becoming a personal physician, my motivation to help that student is intensified. After all, the decisions made during this period are crucial.

I ask the student why he or she went to medical school. A review of the student's career image before medical school is insightful and helps the student step back from the influence of recent experiences. Students can become jaded by recent experiences on clerkships and lose some of the ideals that brought them into medicine. They are often surprised when I, a fully trained physician, suggest that their early ideals are more objective and appropriate to career thinking than the feelings they are carrying from recent experiences.

When a student expresses multiple career interests, I suggest that family practice offers an opportunity to "have it all." That is when the doubts about family practice come forward. I listen to the student respectfully and provide a gentle response based on as much factual information as possible. ${ }^{2}$ Arguing concepts, feelings, and opinions is rarely helpful. Rather, I say to the student, "Let me tell you about being a family physician." 
I talk about the personal relationships, the intense experiences, how 2 days are never the same. I talk about the joys, the frustrations, but most of all the satisfaction of being a personal physician to people and families and in a community. I review with the student a typical day, week, or month. In some ways, this advising session is like a 1-hour preceptorship.

After the student has been heard, after all doubts and feelings are put on the table, the student is ready to listen with keen interest. Often the student challenges whether the role of a personal physician is still possible. "What about managed care?" These fears are addressed compassionately. I explain that what is changeless about family practice, the role of being a personal physician to the family, is more enduring than any changes in practice structure and economics. If we somehow lose the family physician, it will have to be reinvented, because it is what families need first in health care. The students today represent the next generation.

If the student has listened intently and still expresses interest in caring for children and adults, I say, "you sound like a family physician." Often, there is a pregnant pause, a magical moment. I then suggest a real preceptorship as soon as the 4th year starts to test or reinforce what has been said. The preceptor is chosen carefully, matching the particular career interests of the student (eg, women's health, adolescent care, sports medicine).

To engage a student in this manner is not salesmanship. It is an enabling process, intended to resurrect the career interest that has been covered up by narrow thinking and limited experiences. Of course, not all students from such encounters select family practice. The goal is to help all students make their best career decision, and students choosing other fields still appreciate the deep concern for their welfare.

Medical students deserve a positive, motivating view of the future. Most of the frustrations and problems of today will be gone or different when they finish their training. The best preceptors cut through the noise of current political and management issues and get to the essence of being a physician. Yes, this can be done in 1 hour.

\section{References}

1. Block SD, Clark-Chiarelli N, Peters AS, Singer JD. Academia's chilly climate for primary care. JAMA 1996;276:677-82.

2. Scherger JE, Beasley JW, Gaebe GI, Swee DE, Kahn NB, Rodney WM. Responses to questions about family practice as a career. Am Fam Physician 